\title{
A VIRTUAL AUTODESK-SIMULINK REFERENCE PLANT FOR WASTEWATER TREATMENT
}

\author{
T. A. Fashanu ${ }^{1,}{ }^{*}$, J. P. Eche ${ }^{2}$, J. Akanmu ${ }^{3}$, O. J. Adeyeye ${ }^{4}$ and E.E. Atojunere ${ }^{5}$

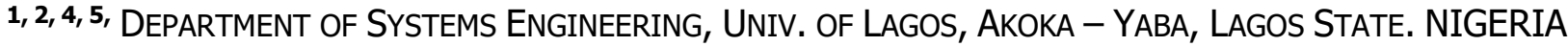 \\ 3, DePt of Civil And EnVironmental Engineering, Univ. OF LAGOS, AKOKA - YABA, LAGOS STATE. NIGERIA \\ E-mail addresses: ${ }^{1}$ tfashanu@unilag.edu.ng, ${ }^{2}$ johnecheoche@gmail.com, 3 jakanmu@unilag.edu.ng, \\ ${ }^{4}$ jadeyeye@unilag.edu.ng, ${ }^{5}$ eatojunere@unilag.edu.ng
}

\begin{abstract}
This work developed a reconfigurable Simulink-Autodesk Inventor similitude of multistage processes involved in medium scale urban runoff wastewater treatment plants WTPs. The reenactment approach for wastewater handling is modelled with detailed attention to its fundamental stages. Parameter identification techniques were used for stream improvement processes to realize a flexible and practicable virtual plant. Simulation results were obtained for wastewater treatment in the grit chamber, activated charcoal, coagulation and sedimentation basins respectively. Reduction in sand concentration and the volumetric flow rate of feedstock to effluent are $750 \mathrm{~g} / \mathrm{l}$ to $0.03745 \mathrm{~g} / \mathrm{l}$ and $400 \mathrm{l} / \mathrm{s}$ to $120 \mathrm{l} / \mathrm{s}$ respectively. The corresponding sedimentation speed is recorded as $0.05718 \mathrm{~mm} / \mathrm{s}$. The grit filters dry matter from $0.6 \mathrm{~g} / \mathrm{l}$ to $0.048720 \mathrm{~g} / \mathrm{l} ;$ to realize $92 \%$ reduction of original dry matter in the feedstock. Thus, a prototype framework for input-process-output response analysis of an efficient wastewater treatment plant is developed to guide the design and implementation of new WTPs as well as optimize operations in existing facilities.
\end{abstract}

Keywords: Wastewater, Treatment Plant, Matlab Simulink, Autodesk Inventor

\section{NOMENCLATURE:}

WTP: Wastewater Treatment Plant

$P I \& D \quad$ Piping and Instrumentation Diagram

$x \quad$ Size of the sand grains

$g \quad$ Acceleration due to gravity $\left(9.81 \mathrm{~m} / \mathrm{s}^{2}\right)$

$\rho \quad$ Water density

$\Delta \rho \quad$ Density difference between sand and water.

$t \quad$ Drag coefficient (assumed to be 1.2)

$Q \quad$ Volumetric flow rate scaled with required capacity of the pump and the sedimentation tank.

$C_{f a} \quad$ Concentration of the flocking agent to be added.

$C_{D O C} \quad$ Concentration of the dissolved organic carbon in the water.

$C_{A l \text {,old }}$ Concentration of alums in the raw water

$C_{A l \text {,new }}$ Concentration of alum after adding flocking agent

$C_{C l \text {,old }}$ Concentration of chloride in raw water

$C_{C l \text {,new }}$ Concentration of chloride after adding flocking agent

$C_{D O C, \text { old }}$ Concentration of dissolved organic carbon in the raw water
$C_{\text {DOC,new }}$ Concentration of dissolved organic carbon after adding flocking agent.

$C_{d m \text {,old }}$ Concentration of dry matter in the inflow to Sedimentation basin (g/l).

$C_{d m \text {,new }}$ Concentration of dry matter in the outflow of Sedimentation basin $(\mathrm{g} / \mathrm{l})$

$K \quad 3.6$, which conversion factor from $\mathrm{g} / \mathrm{s}$ to $\mathrm{kg} / \mathrm{h}$

$g / s$ gram per seconds

$g / l \quad$ gram per liter

$\mathrm{kg} / \mathrm{h}$ Kilogram per hour

$C_{\text {out }}$ Concentration of dry matter at the outflow of the filter

$C_{\text {in }} \quad$ Concentration of (organic) dry matter at the inflow of the filter

$Z \quad$ Thickness of the layer of filtering material (2m)

$\lambda \quad$ Efficiency parameter of the filter.

$t_{d}$ Detention time i.e. time required for water to pass the chamber horizontally

$d_{\text {flake }}$ Size of generated flakes

$V_{\text {sed }}$ Sedimentation velocity $(\mathrm{m} / \mathrm{s})$

$V$ Volume of the chamber in $\mathrm{m}^{3}$

$Q \quad$ Volumetric flow rate $(l / s)$ 


\section{INTRODUCTION}

Water is the most essential substance for life [1] and it is vital for human wellbeing. Despite its abundance on earth, potable water is relatively scarce. However, raw and wastewater of varied sources abound in all settlements. To meet communal safety requirements, raw water of surface and underground origins as well as wastewater from domestic and industrial streams are often treated at municipal water treatment plants (WTPs). The conceptual framework of most facilities are similar. However, design and installation of specific plant are often challenged by scale effect and wide-range variability in physical and biochemical properties of feedstock.

Most human activities and settlements benefit from clean and potable water. However, brackish waste and runoff water logged environments are unsafe for human habitation. Similarly, unabated exposure to raw sewage and industrial wastewater also constitute health hazards. Without prompt treatment, wastewater streams will ultimately contaminate domestic freshwater source to endanger communal health. As a result, wastewater treatment is critical to the stability and sustainability of modern communities. Often, wastewater treatment is a medium to large-scale municipal project. The goal is to detoxify and restore wastewater to an admissible standard [2]. These plants are vital units of the water cycle. They support natural system of freshwater restoration and preservation. Mostly, their basic operations include; physical removal of floatable and settling solids in addition to bio-chemical removal of dissolved solids and microbes. However, plant scales and configuration varies from one settlement to the other due to significant differences in volume and quality of raw water as well as available resources. Irrespective of local constraints, processed wastewater should meet water quality standard prescribed by the World Health Organization (WHO). This work prototypes basic processes of conventional water treatment system with Matlab/Simulink blocks to develop a generalized reference WTP. It identifies important state variables in the basic processes of a WTP and develops linear mathematical models to represent their dynamics. The conceptual design is adaptive model reference approach to streamflow in the processing units. Subsequently, stream flow charts and algorithms derived from the system dynamics were used to build Simulink block prototype of the conceptual WTP. This enabled validation and performance analysis of the reference plant. The model plant accepts and process a wide range of feed water quality to variable degrees of purity. Therefore, it will serve as a flexible tuning platform for WTP design and implementation engineers as well as other wastewater practitioners.

\section{OVERVIEW OF WASTEWATER TREATMENT PROCESSES}

Conventional water treatment accepts raw water as feedstock. This may include groundwater and surface water. These processes, in treatment for portable water, consist of coagulation, sedimentation, filtration and disinfection.

Coagulants coagulate some unwanted matter in wastewater. It flocculates by inducing collusion between tiny suspended materials and colloidal particles in water that are hard to separate by natural sedimentation [3]. Subsequently, the sedimentation process separates large flocs from water by gravitational force. In some plants, clarification replace coagulation and sedimentation. The combined processes complement a treatment unit. Filtration uses granular filters to intercept residual particles in water after sedimentation. It lowers the final water turbidity. Disinfection is the last unit of treatment process. Disinfectant such as liquid chlorine inactivate pathogenic microorganisms. Summarily, the plant removes suspended solids, colloidal materials, and pathogens from raw water to meet stringent standards stipulated for admissible wastewater.

\subsection{Water Treatment Materials and Procedure}

Raw water usually consists of high concentration of iron, hydrogen sulphide $\left(\mathrm{H}_{2} \mathrm{~S}\right)$ and dissolved solids. Its other constituents are some nonferrous and heavy metals, insoluble salts and other particles [4]. These are often coagulated by Sodium Hydroxide $(\mathrm{NaOH})$, Sodium Hypochlorite, and Aluminum Sulphate $\mathrm{Al}_{2} \mathrm{SO}_{4} \cdot 14 \mathrm{H}_{2} \mathrm{O}$. Generally, water treatment procedure are classified as primary and secondary processes.

\subsection{Primary Treatment}

Primary water treatment stages remove physical materials. They use physical techniques and quantities to remove large and medium sized particles. Figure 1 is the schematics of primary treatment plant; the basic stages are: 
Screening that uses bars to remove wood, stones, and other large debris from feedstock.

Pumping that strategically lifts less dense wastewater from dense physical waste for further treatment. Grit removal separates materials such as sand and other dense particles through aeration and floatation process. Clarification is the sedimentation process where heavier sludge settles to the bottom.

In its basic form, the primary treatment stage of WTP consists of mechanical processes. This stage removes almost half of the contaminants. Hence, dissolved compounds that scaled clarification stage and microbial organisms are processed using chemical and biological techniques at the secondary stage.

\subsection{Secondary Treatment}

Pre-processed wastewater from the primary clarifier is the input to the secondary clarifier tanks. Here, scum fraction is further reduced by passing the waste through a cascade of filtration media. Figure 2 is a flow diagram of a typical secondary treatment process.

At this stage, common chemical wastes are phosphates and nitrates. Here, bacteria and other microorganisms cells remove the pathogens.

\subsubsection{Aeration}

Aeration process involves bringing air and wastewater together in turbulent contact to provide oxygen for metabolism of microorganism and facilitate microbiological degradation of organic matter. In addition, the process significantly reduces dissolved carbon dioxide(s), oxidize irons and manganese as well as stripes ammonia and hydrogen sulphide in wastewater. The chemical reactions involved for inorganic processes are described below this page.

Clearly, the available concentration of oxygen controls the outcome of aeration process. Oxygen supply is usually assessed with respect to the overall biochemical oxygen demand BOD. This is determined by the efficiency of the aeration process. Based on the process frequency, the basic mathematical expressions for the efficiency of the aeration process are determined by the difference between available oxygen and total oxygen demand expressed in equation (4) to (7) respectively.

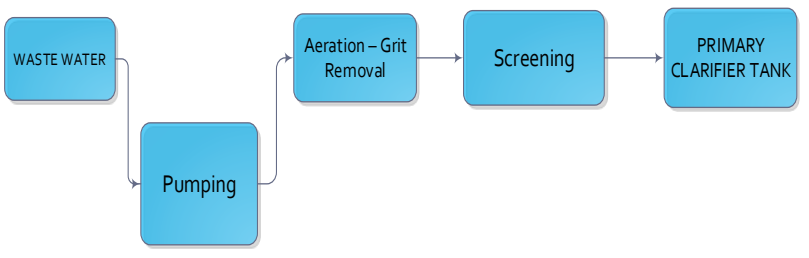

Figure 1: Flow diagram of Primary Treatment of WTP.

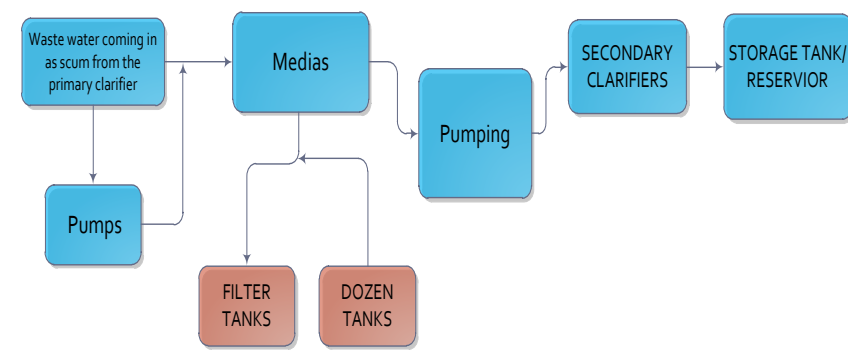

Figure 2: Flow diagram of the secondary treatment in a WTP

\begin{tabular}{lll}
\hline \hline $\mathrm{Fe}\left(\mathrm{HCO}_{3}\right)_{2}$ & $+\mathrm{O}_{2}+2 \mathrm{H}_{2} \mathrm{O}=4 \mathrm{Fe}(\mathrm{OH})_{3}+8 \mathrm{CO}_{2}$ & $\mathrm{CHE}(1 \mathrm{a})$ \\
$\mathrm{CHE}\left(\mathrm{CC} 2 \mathrm{Mn}\left(\mathrm{HCO}_{3}\right)_{2}+\mathrm{O}_{2}=2 \mathrm{MnO}_{2}+4 \mathrm{CO}_{2}+2 \mathrm{H}_{2} \mathrm{O}\right.$ & $\mathrm{CHE}(1 \mathrm{~b})$
\end{tabular}

Products of oxidation are removed by filtration. Similarly, the de-carbonization process follows through the following reaction;

$\mathrm{H}_{2} \mathrm{O}+\mathrm{CO}_{2} \ll » \mathrm{H}^{+}+\mathrm{HCO}_{3}^{-}$

Also, the removal of hydrogen sulphide and ammonia proceed as;

$$
\begin{aligned}
& \mathrm{H}_{2} \mathrm{~S} \text { « } \mathrm{H}^{+}+\mathrm{HS}^{-} \\
& \mathrm{H}_{2} \mathrm{O}+\mathrm{NH}_{3} \text { « } \mathrm{NH}_{4}^{+}+\mathrm{OH}^{-}
\end{aligned}
$$


Effective oxygen demand ratio in the WTP process $\theta_{2 M r}$ is given as;

$$
\theta_{2 M r}=\theta_{2 S p} L_{H}
$$

Thus, the hydraulic load $\left(L_{H}\right)$ is a ratio of two oxygen demands. Where $\theta_{2 S p}$ is the specific oxygen demand per hydraulic load in an aerated tank for a wastewater flow rate $Q$. Therefore, the food to microorganism (F/M) ratio $R_{f m}$ evaluates as;

$$
R_{f m}=\frac{Q \cdot L_{H}}{V_{A} \cdot A_{S}}
$$

Equation (5) is consistent with the expression of [5] where the metric unit of $R_{f m}$ is given as gBOD5/gSS. $d, V_{A}$ is the aerated tank volume, $m^{3}$

$A_{S}$ is activated sludge concentration in the aerated tank, $\mathrm{g} / \mathrm{m}^{3}$.

Therefore, the activated sludge concentration $C_{X S}$ per mass flow rate in a treatment process is:

$$
C_{X S}=\frac{Q \cdot L_{H}}{R_{f m} A_{S r} \cdot Q_{W A S}}
$$

Such that; $A_{S r}$ is the recirculating activated sludge concentration per unit volume in $\mathrm{g} / \mathrm{m}^{3}$, $Q_{W A S}$ is the waste activated sludge flow rate, $m^{3} / h$.

If a flow rate $Q_{r}$ is defined as the recirculated concentration with a corresponding recirculated sludge concentration $r_{X S}$, then the activated sludgerecirculating ratio approximates as,

$$
r_{X S}=\frac{\left(A_{S r}-A_{S}\right)}{A_{S}}
$$

Clearly, the activated sludge ratio $r_{X S}$ in equation (7) is an index of oxygen ratio and it determines the performance of the aeration tank.

\section{PROCESS MODELLING AND DEVELOPMENT OF SIMULINK BLOCKS}

Following the outline of processes described, this work developed a functional reference for wastewater treatment plant through system modelling and parameter identification. The Simulink Blocks consist of mathematical equations representing input-output relationship of state variables in each stage of the treatment plant. Subsequently, test runs of sample treatment operations were simulated on the Simulink Blocks in Matlab R2013a environment. Results obtained were validated using available wastewater processing data.

\subsection{Mathematical Modelling}

Modelling of wastewater treatment plant simulate processing mechanism of the plant. It takes wastewater as the input and respond with variable quality of treated water. The dynamics of the inputoutput processes are represented with appropriate rate equations. The model is developed in modular form to represent the multistage processes involved in water treatment operations. Layout of the proposed virtual plant as configured by Autodesk Inventor Professional V2017 is shown in Figure 3. It describes the Piping and Instrumentation Diagram (PID) that makes up the different units of the WWTP. To highlight the constituents of one of the processing units, Figure 4, gives an orthographic view of the Clarifier plant. The process flow chart of the treatment stages is illustrated in Figure 5. The chart describes the coupling between the single stage processes that are integrated in WTP.

Simulink implementation of the WTP model is shown in Figure 6. Parameters on Table 1 were used to test the model. The simulation followed outlined mathematical equations. Results obtained were used to test the model developed in Figures 5 to 8 . Simulation outcome are shown in Tables 3-6 for each of the treatment processes. The simulated treated water quality meets WHO standards for purity of treated water

\subsubsection{Water Parameter Model}

Flow diagram of the secondary stages of water treatment is shown in Figure 2. A pilot plant configured according to the reference plant informed the choice of parameters in Table 1. These parameters form the basis for estimating the efficiency of the treatment plant.

\subsubsection{Model Description}

Simulink Blocks prototyping the input-process-output systems representing stage of the reference plant are configured according to the flow chart in Figure 5. Feedstock parameters are selected from Table 1 and the scopes display realized states of processed water after simulated runs at the end of each stage of the reference plant. The process equations at each stage are as presented in Sub-section 3.1.3. 


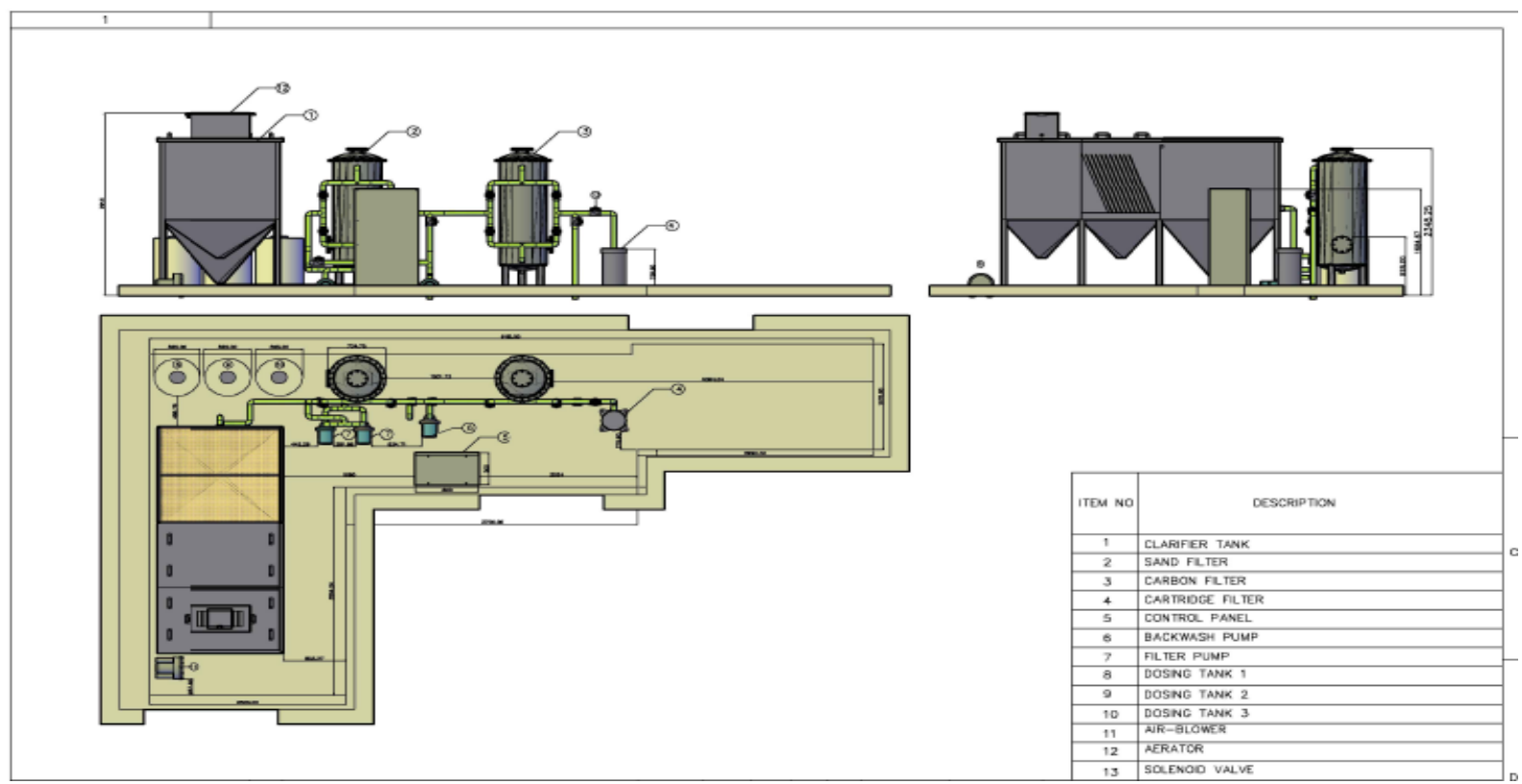

Figure 3: Piping and Instrumentation Diagram of the WTP Model

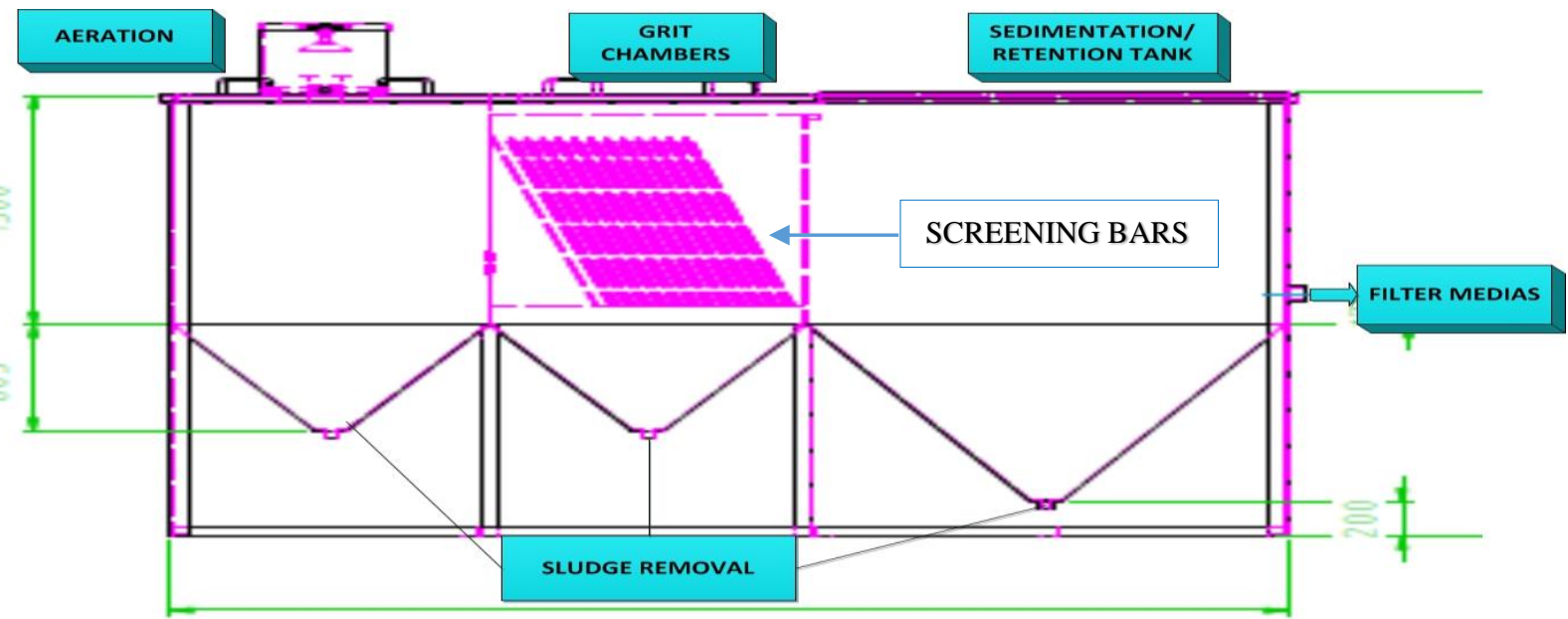

Figure 4: Orthographic View of the Clarifier Tank

\subsubsection{Process Equations at the Grit Chamber}

At the grit chamber, we consider the sedimentation velocity given by [6]

$$
\mathrm{v}_{\text {sed }}=\sqrt{\frac{4}{3} \cdot \frac{x \cdot \Delta \rho \cdot \mathrm{g}}{\mathrm{t} \cdot \rho}}
$$

Where the time needed for the water to pass through the chamber horizontally is given as.

$$
\mathrm{t}_{\mathrm{a}}=\frac{\mathrm{V}}{\mathrm{Q}} \quad[\text { seconds }]
$$

and

$$
V=\mathrm{V} \times(l \times b \times h)
$$

\subsubsection{Process Equations at the Coagulation Basin}

The coagulation basin combines the input and output water parameters of the grit chamber.
However, the concentrations of flocking agent is determined by [7] as:

$$
\mathrm{C}_{\mathrm{fa}}=\frac{\mathrm{C}_{\mathrm{DOC}}-0.6286}{1.7143}
$$

Meanwhile, concentrations of alum and chloride are estimated by [8] as:

$$
\begin{gathered}
\mathrm{C}_{\mathrm{Al}, \text { new }}=\mathrm{C}_{\mathrm{Al}, \mathrm{old}}+0.28 \cdot \mathrm{C}_{\mathrm{fa}} \\
C_{C l, \text { new }}=C_{C l, \text { old }}+0.368 \cdot C_{f a}
\end{gathered}
$$

Similarly, to eliminate dissolved organic compound (DOC) in the water, we consider the expression of [9] given as:

$$
\begin{aligned}
& C_{D O C, \text { old }} \\
& =C_{D O C, \text { old }}-\frac{C_{D O C, \text { old }}-\left(14.314 \times \ln C_{\mathrm{fa}}-6.1091\right)}{100}
\end{aligned}
$$

Finally the turbidity is determined by [10] as: 


$$
T_{d}=65.795 \times\left(e^{\left(-0.806 * c_{f a}\right)}\right)
$$

Similarly the size of the generated flakes is determined by [11] as:

$$
\begin{gathered}
d_{\text {flake }}=-0.1327 \times\left(\frac{t_{d}}{60}\right)^{2}+12.667 \times \frac{t_{d}}{60}-32.9 \\
t_{d}=\frac{V}{Q}
\end{gathered}
$$

Where $t_{d}$ is the detention time in seconds.

\subsubsection{Process Equations at the Sedimentation Basin} Apart from geometrical shape, the design of chamber is similar to sedimentation basin. Instead of the size of the grit, the flake size and density are used as process parameters. The flake density is taken as $1050 \mathrm{~g} / \mathrm{l})$, and its drag coefficient is assumed as 1.8. Another difference is that dry matters settle at the sedimentation basin instead of sand. Therefore, to compute the new concentration of dry matter, it is necessary to determine the amount of sludge produced. Thus, according to [8], the amount of sludge is expressed as,

$$
\text { Amount }_{\text {sluge }}=Q \times\left(C_{d m, \text { old }}-C_{d m, \text { new }}\right) \times K
$$

The corresponding concentration of organic dry matter after filtering is obtained as;

$$
C_{\text {out }}=C_{\text {in }} \times e^{-\lambda \cdot Z}
$$

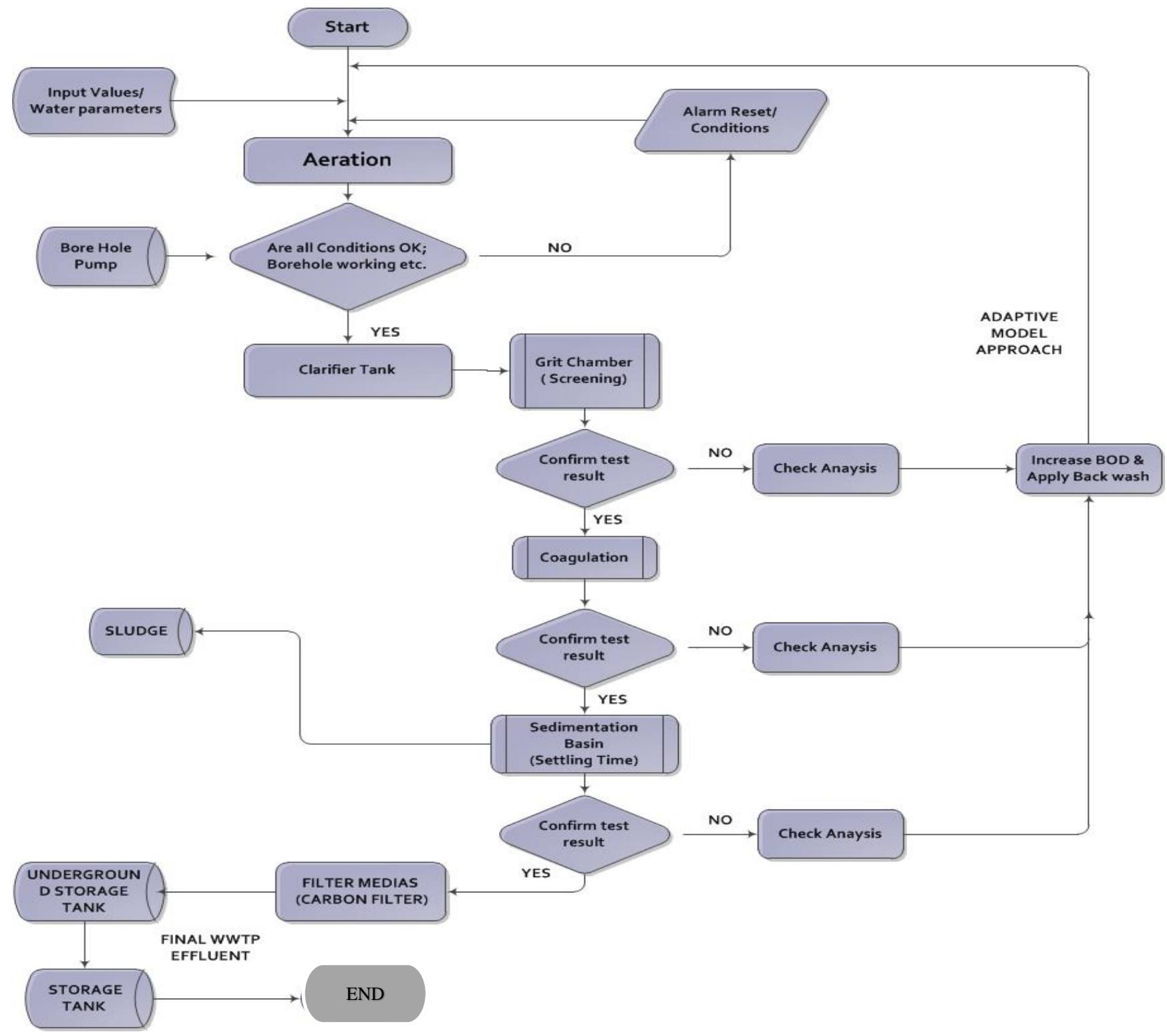

Figure 5: Process Flow Chart for the Piping \& Instrumentation Diagram of the WWTP Model. 


\subsection{Simulink Reference Blocks}

Consistent with the overall objective, the developed Simulink reference plant as shown in Figures 6-8 represents key stages of the primary and secondary wastewater treatment processes. The blocks for each stage embed the mathematical model of the corresponding physical or chemical activities simulated by the subsystem. The subsystem transforms input water quality to output water quality. However, output of one stage is input of next stage in a way that follows the process flow diagram in Figure 5.

Basic and detailed subsystems of the coagulation basin in Simulink Blocks are presented in Figures 7 and 8.
Table 1: Influent Water Parameters

\begin{tabular}{lll}
\hline S/No. & Input & Parameter \\
\hline 1 & Sand concentration & $750 \mathrm{mg} / \mathrm{l}$ \\
2 & Mass density & $999.976 \mathrm{~g} / \mathrm{l}$ \\
3 & $\begin{array}{l}\text { Concentration of other } \\
\text { materials }\end{array}$ & \\
& Aluminium & $0.2323 \mathrm{mg} / \mathrm{l}$ \\
4 & Dissolved organic carbon & $12.64 \mathrm{mg} / \mathrm{l}$ \\
6 & Chloride & $300 \mathrm{mg} / \mathrm{l}$ \\
7 & Dry matter & $1.8 \mathrm{~g} / \mathrm{l}$ \\
8 & Organic dry matter & $0.6 \mathrm{~g} / \mathrm{l}$ \\
9 & E. Coli & $985 / \mathrm{I}$ \\
10 & Coliform bacteria & $1010 / \mathrm{I}$ \\
11 & Enterococci & $284 / \mathrm{l}$ \\
12 & Turbidity & $23.4 \mathrm{NTU}$ \\
13 & Sand grain size & $0.002 \mathrm{~m}$ \\
14 & Maximum volumetric flow rate & $400 \mathrm{l} / \mathrm{s}$ \\
\hline
\end{tabular}

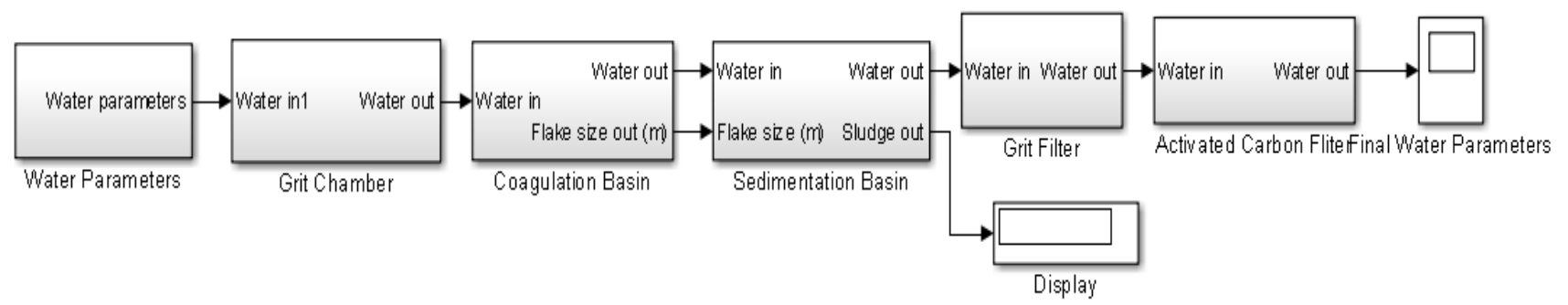

Figure 6: Simulink Blocks of the Basic Stages in the Reference Plant

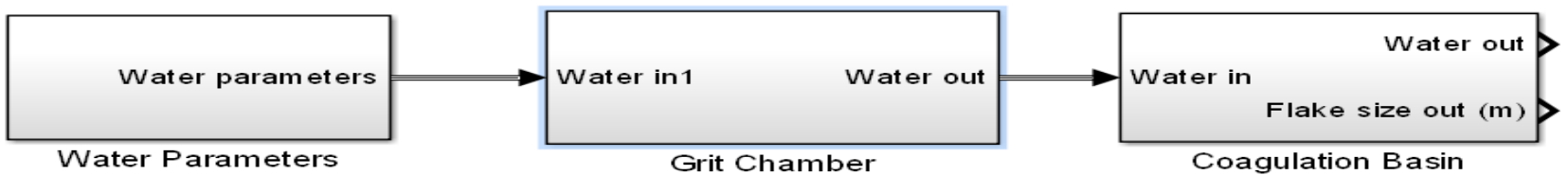

Figure 7: Simulink Scheme for the Coagulation Basin

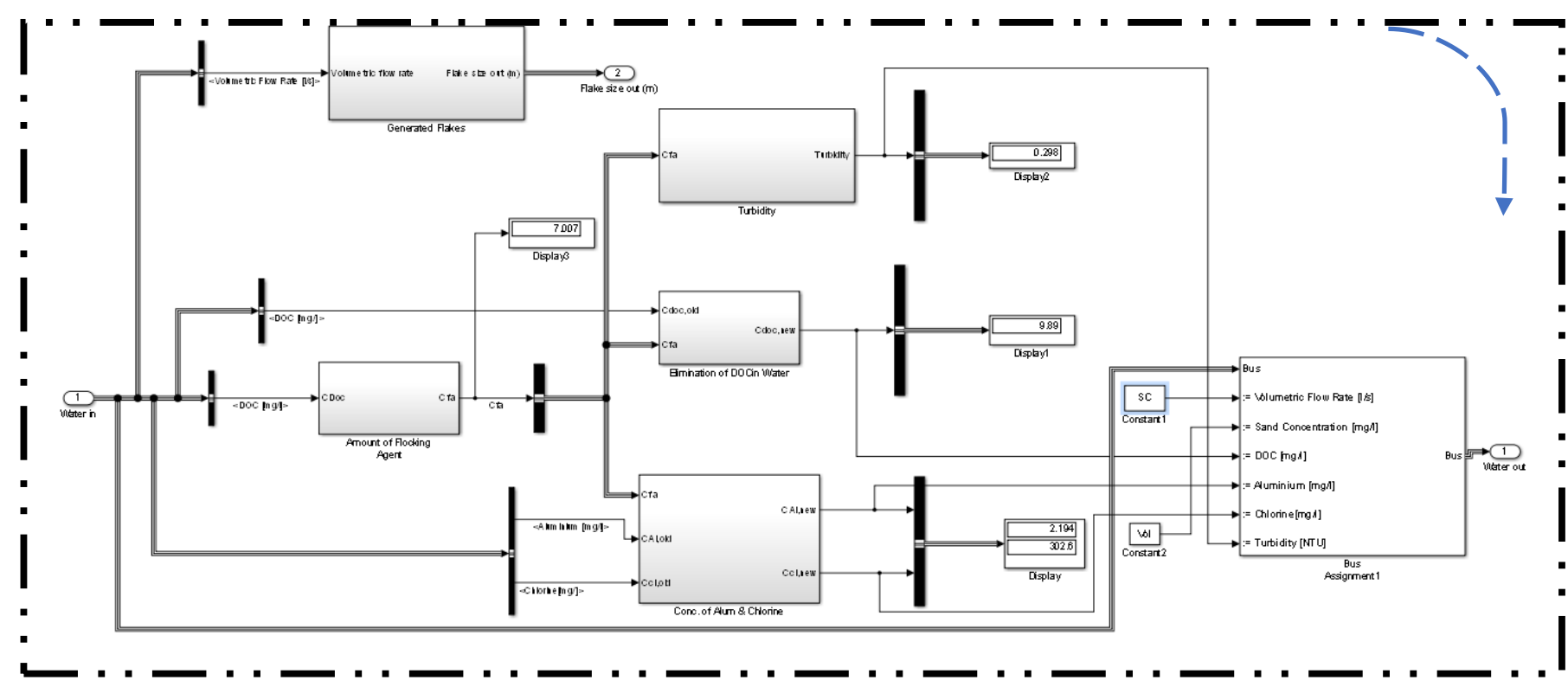

Figure 8: Expanded/Subsystem in the Simulink Block of the Modelled Coagulation Basin 


\subsubsection{Simulation Parameters}

Some specific feedstock parameters during the initial test stage of the sampled water were scaled to broaden the scope of simulation and standardize the results of each stage of the simulation process. These results are iteratively assessed with the WHO benchmark.

In line with standard practice; for the simulation, treatment processes are divided into two stages primary and secondary, as illustrated in the methodology. For the primary treatment, the four basic processes are simulated. In addition, in the secondary treatment, cartridge and multi-media sand filtration was used. Other ancillary treatment include, sedimentation and aeration in the grit chambers etc.

\section{RESULTS AND DISCUSSION}

The reference plant was simulated with collected data. Its results were validated by [8], in line with [12]. Figure 9 shows a sample outcome of stagewise water treatment as processed by the reference plant. The results of each compartment are detailed in sections $4.1-4.4$.

Sample GUI for generating similar results e.g. for the coagulation basin is shown in the Appendix.
Table 2: Simulation Result for the Grit Chamber

\begin{tabular}{|c|c|c|}
\hline S/No. & Input & Parameter \\
\hline 1 & Sand concentration & $750 \mathrm{mg} / \mathrm{l}$ \\
\hline 2 & Mass density & $999.976 \mathrm{~g} / \mathrm{l}$ \\
\hline 3 & \multicolumn{2}{|c|}{$\begin{array}{l}\text { Concentration of Inorganic/Organic Matters } \\
\text { and Microbes }\end{array}$} \\
\hline 4 & Aluminium & $0.2323 \mathrm{mg} / \mathrm{l}$ \\
\hline 5 & Dissolved organic carbon & $12.64 \mathrm{mg} / \mathrm{l}$ \\
\hline 6 & Chloride & $300 \mathrm{mg} / \mathrm{l}$ \\
\hline 7 & Dry matter & $1.8 \mathrm{~g} / \mathrm{l}$ \\
\hline 8 & Organic dry matter & $0.6 \mathrm{~g} / \mathrm{l}$ \\
\hline 9 & E. Coli & $985 / I$ \\
\hline 10 & Coliform bacteria & $1010 / /$ \\
\hline 11 & Enterococci & $284 / /$ \\
\hline 12 & Turbidity & 23.4 NTU \\
\hline 13 & Sand grain size & $0.002 \mathrm{~m}$ \\
\hline 14 & $\begin{array}{l}\text { Maximum volumetric flow } \\
\text { rate }\end{array}$ & $400 \mathrm{l} / \mathrm{s}$ \\
\hline 15 & Sedimentation speed & $0.05718 \mathrm{~mm} / \mathrm{s}$ \\
\hline 16 & Sand concentration & $0.03745 \mathrm{~g} / \mathrm{l}$ \\
\hline 17 & Volumetric flow rate & $120 \mathrm{l} / \mathrm{s}$ \\
\hline
\end{tabular}

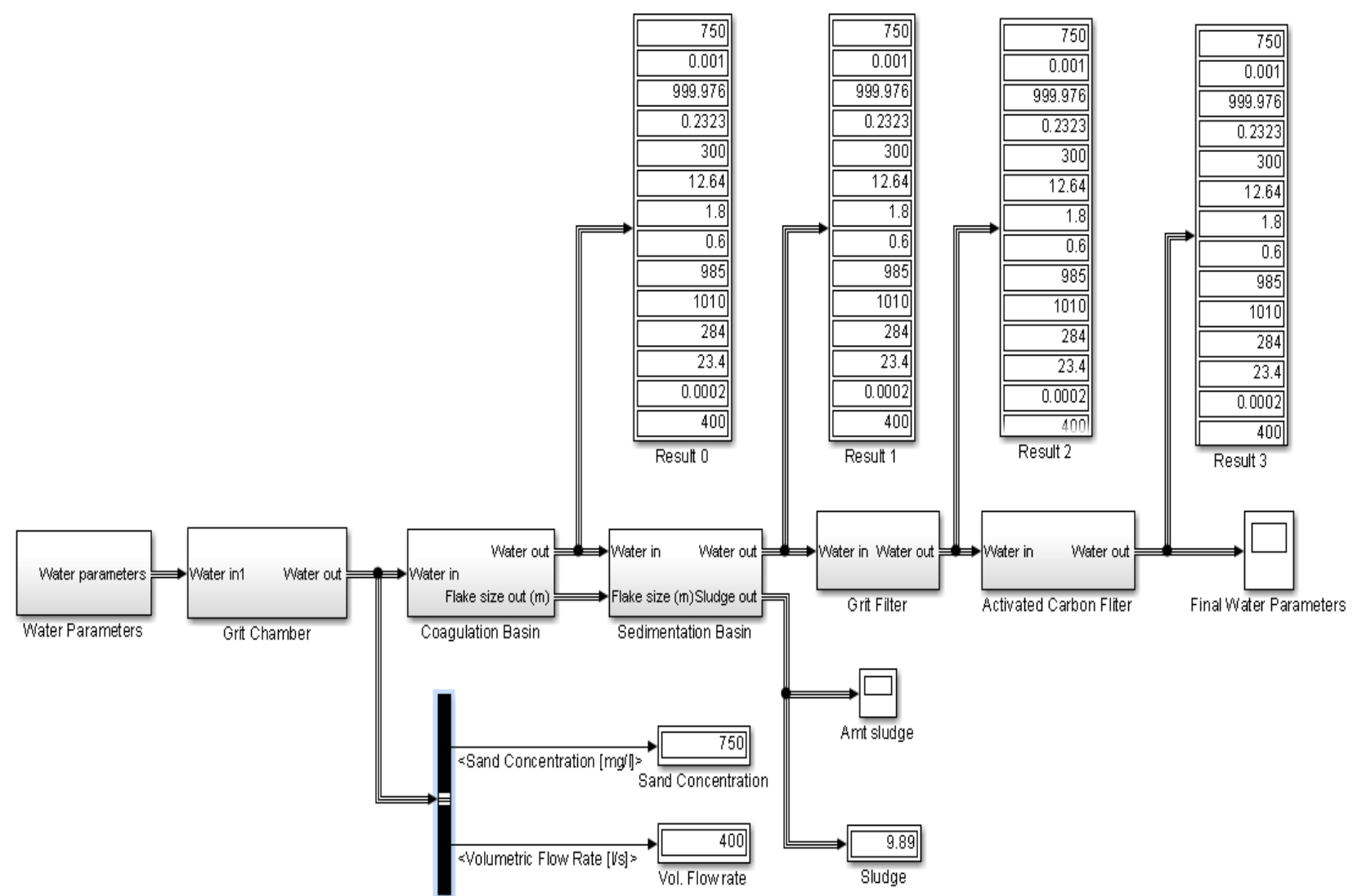

Figure 9: Sample Simulink Input-Output Scope Results for Simulated Stages of Wastewater Treatment Plant 
In the grit chamber, the governing equations transform grit concentration from its value when water enters the chamber to the outflow value. For sustainability, at this stage, sand concentration should be optimum [12], and its relationships with the performance of aeration sub system are indicated in Figure 6. However, the primary objective of aeration is to separate wastes that are denser than water by pumping sufficient amount of air via the orifice/shower cap. Compared with Table 1; Table 2 shows that water parameters of the feedstock are relatively unchanged. Hence, grit concentration is only updated in the Simulink Block of coagulation basin and or grit chamber.

As expected, the degree of grit reduction and sedimentation depends on the retention time. Simulation shows sharp reduction in volumetric flow rate at the pump as seen in Tables 3 and 4; the flowrate drops from $400 \mathrm{l} / \mathrm{s}$ to $120 \mathrm{l} / \mathrm{s}$. Therefore, sludge leaves the systems at about $9.89 \mathrm{~kg} /$ cycle. Similarly, the amount of flocking agent, dry matter to water and turbidity value of the basin effluent water are computed. Clearly, concentration of dissolved oxygen, flake size as well as concentration of aluminum and chlorides in treated water meet WHO requirement for acceptable treated water.

At the filtration stage, results shown in Table 5 indicate that concentration of dry matter contained in the effluent of sedimentation basin is the target variable.

\section{Table 3: Simulation Result for the Coagulation Basin}

\begin{tabular}{lll}
\hline S/No. & Input & Parameter \\
\hline 1 & Sand concentration & $0.037443 \mathrm{mg} / \mathrm{l}$ \\
2 & Viscosity coefficient & 0.001 \\
3 & Mass density & $999.976 \mathrm{~g} / \mathrm{l}$ \\
4 & Concentration of Inorganic/Organic Matters \\
5 & and Microbes & \\
6 & Aluminium & $2.2 \mathrm{mg} / \mathrm{l}$ \\
6 & Dissolved organic & $9.889 \mathrm{mg} / \mathrm{l}$ \\
7 & carbon & $302.5784257 \mathrm{mg} / \mathrm{l}$ \\
8 & Chloride & $1.807 \mathrm{~g} / \mathrm{l}$ \\
9 & Organic dry matter & $0.6 \mathrm{~g} / \mathrm{l}$ \\
10 & E. Coli & $985 \mathrm{I}^{-1}$ \\
11 & Coliform bacteria & $1010 \mathrm{I}^{-1}$ \\
12 & Enterococci & $284 \mathrm{I}^{-1}$ \\
13 & Turbidity & $0.2980 \mathrm{NTU}$ \\
14 & Sand grain size & $0.002 \mathrm{~m}$ \\
15 & Maximum volumetric & $120 \mathrm{l} / \mathrm{s}$ \\
\hline
\end{tabular}

Table 4: Simulation Result for the Sedimentation Basin

\begin{tabular}{|c|c|c|}
\hline S/No. & Input & Parameter \\
\hline 1 & Sand concentration & $0.037443 \mathrm{mg} / \mathrm{l}$ \\
\hline 2 & Viscosity coefficient & 0.001 \\
\hline 3 & Mass density & $999.976 \mathrm{~g} / \mathrm{l}$ \\
\hline 4 & \multicolumn{2}{|c|}{$\begin{array}{l}\text { Concentration of Inorganic/Organic Matters } \\
\text { and Microbes }\end{array}$} \\
\hline 5 & Aluminium & $2.1941456512862 \mathrm{mg} / \mathrm{l}$ \\
\hline 6 & $\begin{array}{l}\text { Dissolved Organic } \\
\text { Carbon }\end{array}$ & $9.889 \mathrm{mg} / \mathrm{l}$ \\
\hline 7 & Chloride & $202.5784257 \mathrm{mg} / \mathrm{l}$ \\
\hline 8 & Dry matter & $1.89735807 \times 10^{-7} \mathrm{~g} / \mathrm{l}$ \\
\hline 9 & Organic dry matter & $0.6 \mathrm{~g} / \mathrm{l}$ \\
\hline 10 & E. Coli & $985 \mathrm{I}^{-1}$ \\
\hline 11 & Coliform bacteria & $1010 \mathrm{l}^{-1}$ \\
\hline 12 & Enterococci & $\left.284\right|^{-1}$ \\
\hline 13 & Turbidity & .2980 NTU \\
\hline 14 & Sand grain size & $0.002 \mathrm{~m}$ \\
\hline 15 & $\begin{array}{l}\text { Maximum } \\
\text { volumetric flow rate }\end{array}$ & $120 \mathrm{l} / \mathrm{s}$ \\
\hline 16 & $\begin{array}{l}\text { Sludge } \\
\text { Concentration }\end{array}$ & 780.624 \\
\hline
\end{tabular}

\begin{tabular}{|c|c|c|}
\hline S/No. & Input & Parameter \\
\hline 1 & Sand concentration & $0.03745 \mathrm{mg} / \mathrm{l}$ \\
\hline 2 & Viscosity coefficient & 0.001 \\
\hline 3 & Mass density & $999.976 \mathrm{~g} / \mathrm{l}$ \\
\hline 4 & \multicolumn{2}{|c|}{$\begin{array}{l}\text { Concentration of Inorganic/Organic Matters } \\
\text { and Microbes }\end{array}$} \\
\hline 5 & Aluminium & $\begin{array}{l}2.1941456512862 \\
\mathrm{mg} / \mathrm{l}\end{array}$ \\
\hline 6 & $\begin{array}{l}\text { Dissolved organic } \\
\text { carbon }\end{array}$ & $9.889 \mathrm{mg} / \mathrm{l}$ \\
\hline 7 & Chloride & $202.5784257 \mathrm{mg} / \mathrm{l}$ \\
\hline 8 & Dry matter & $\begin{array}{l}1.89735807 \times 10^{-} \\
7 \mathrm{~g} / \mathrm{l}\end{array}$ \\
\hline 9 & Organic dry matter & $0.048720 \mathrm{~g} / \mathrm{l}$ \\
\hline 10 & E. Coli & $985 / 1$ \\
\hline 11 & Coliform bacteria & $1010 / 1$ \\
\hline 12 & Enterococci & $284 / 1$ \\
\hline 13 & Turbidity & $0.2980 \mathrm{NTU}$ \\
\hline 14 & Sand grain size & $0.002 \mathrm{~m}$ \\
\hline 15 & $\begin{array}{l}\text { Maximum volumetric } \\
\text { flow rate }\end{array}$ & $120 \mathrm{l} / \mathrm{s}$ \\
\hline 16 & Conc. Organic matter & $0.821 \mathrm{~g} / \mathrm{l}$ \\
\hline
\end{tabular}

The grit initially reduces dry matter from $0.6 \mathrm{~g} / \mathrm{l}$ to $0.048720 \mathrm{~g} / \mathrm{l}$ and finally to $1.89735807 \times 10^{-7} \mathrm{~g} / \mathrm{l}$. This 
represents about 92 percent reduction of the original amount of dry matter in the feedstock.

\section{CONCLUSION}

This work developed an adaptive simulation model for wastewater treatment processing plant. A library of mathematical models was defined to address each contaminant at specific stages of the wastewater processing plant. In particular, a reference model suitable for handling domestic effluents or wastewater from cottage industry is developed. The prototype was developed in Matlab R2013a Simulink environment. The combined Autodesk InventorMatlab Simulink environment supports further development of the virtual plant by other users.

Model validation was performed through an analysis of stage wise outcome of the reference plant water parameters and corresponding values in literature. Summarily, the reference model can facilitate process recalibration given prior knowledge of the average or expected parameters of wastewater to determine expected purity of treated water.

\section{REFERENCES}

[1] National Aeronautics and Space Administration, "Water: A Chemical Solution," 2017.

[2] O. Ibidapo, T. A. Fashanu, I. O. Peter, A. O. Tope and A. E. Kingsley, "Produced water reinjection in a non-fresh water aquifer with geochemical reaction, hydrodynamic molecular dispersion and adsorption kinetics controlling: model development and numerical simulation," Applied Water Science, Springer Link, vol. VII, pp. 1169-1189, 2017.

[3] M. Malaysia, "Control strategies of wastewater treatment plants," Australian Journal of Basic and Applied Sciences, pp. 446-455, 2011.

[4] United States Environmental Protection Agency, "2018 Edition of the Drinking Water Standards and Health Advisories Tables," 2018.

[5] A. A. Adamu and I. L. Nwaogozie, "Activated Sludge Process Simulator ASP-SIM,Part-1: Bod and Temperature Model.," Global Journal of
Engineering Research, vol. VIII, pp. 1-10, 2010.

[6] Z. Song, T. Wu, F. Xu and R. Li, "A simple formula for predicting settling velocity of sediment particles," Water Science and Engineering, vol. I, pp. 37-43, 2008.

[7] F. Caroline, Untersuchungen zu Eintrag, Verteilung und Verbleib natürlicher organischer Wasserinhaltstoffe aus moorgeprägten, 2006.

[8] D. Peter and H. Hans, "Visualizing Process Information and the Health Status of Wastewater Treatment Plants. Data Visualization, Springer.," 2003, pp. 225-236.

[9] Z. Yang, B. Gao and Y. Qinyan, "Coagulation performance and residual aluminum speciation of $\mathrm{Al} 2(\mathrm{SO} 4) 3$ and polyaluminum chloride (PAC) in Yellow River water treatment," Chemical Engineering Journal , pp. 122-132, 2010.

[10] G. Bao-Yu, C. Yong-Bao, Y. Qin-Yan, W. BingJian and W. Shu-Guang, "Characterization and coagulation of a polyaluminum chloride (PAC) coagulant with high Al13 content," Journal of Environmental Management, vol. 76, no. 2, pp. 143-147, 2005.

[11] P. Zhang, Z. G. Wu Zhen, G. Zeng, H. Zhang, S. $X$. Li Juan and J. Dong, "Coagulation characteristics of polyaluminum chlorides PAC-AI 30 on humic acid removal from water," Separation and Purification Technology, pp. 642647, 2008.

[12] K. E. Abhulimenn, T. A. Fashanu and P. Idialu, "Modeling fracturing pressure parameters in predicting injector performance and permeability damage in subsea well completion multireservoir system," Journal of Petroleum Exploration and Production Technology, Springer Link, vol. VIII, no. 3, p. 813-838, 2018.

[13] Metcalf and Eddy, "Wastewater Engineering, Treatment and Reuse," 2003. 


\section{APPENDIX}

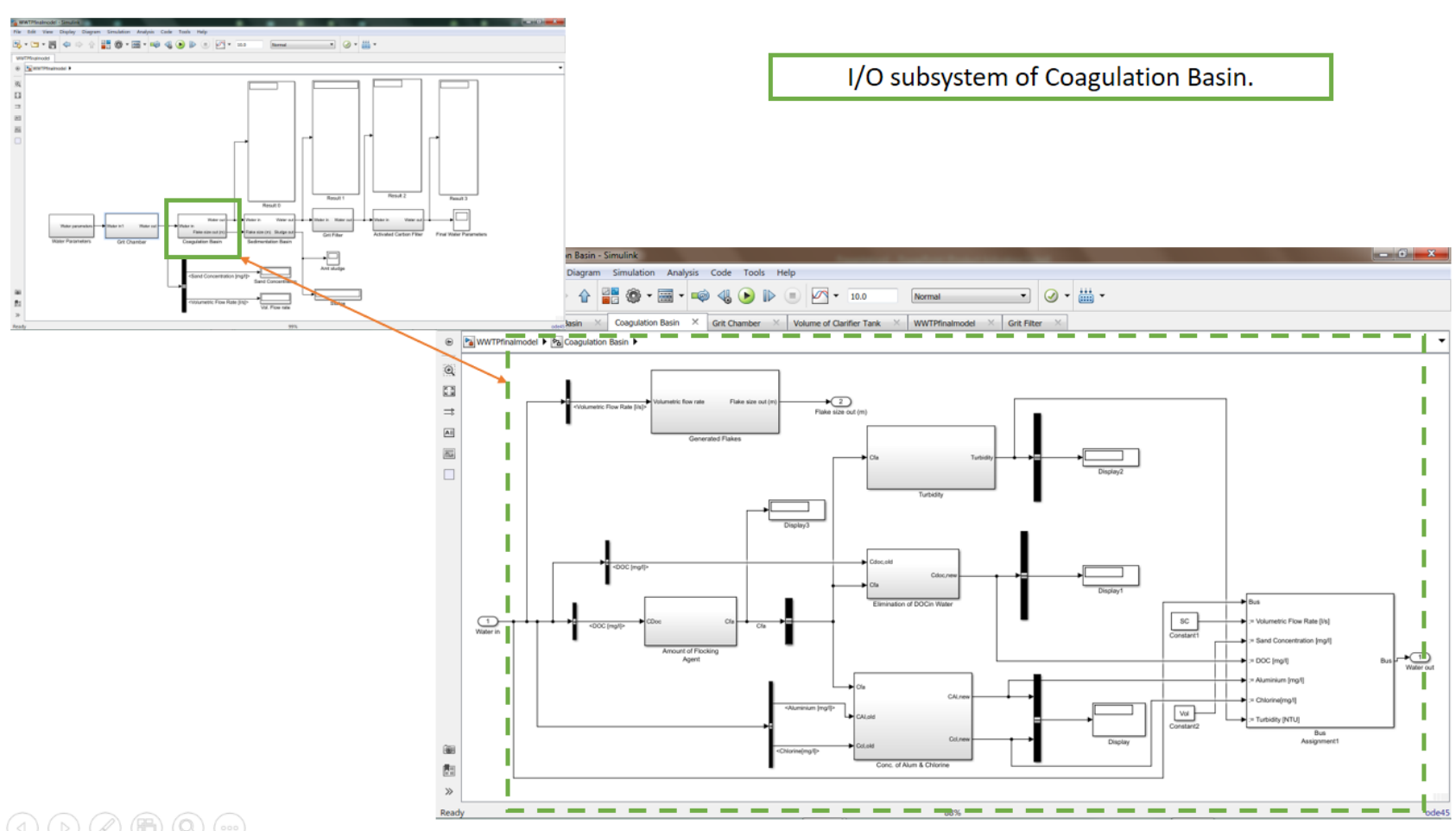

